\title{
UTILIZATION AND PROTECTION OF REGIONAL AUTONOMY-BASED ASSETS TO INCREASE LOCAL REVENUE ${ }^{\Omega}$
}

\author{
Sri Winarsi, Agus Sekarmadji, Oemar Moechthar \\ Law Faculty of Universitas Airlangga Surabaya, Indonesia \\ E-mail: sriwinarsi_fhunair@yahoo.com
}

\begin{abstract}
Land status of management rights of Surabaya City Government known as green letter (surat ijo) sparks controversy among citizens regarding the control and management of the land. Citizens want the con-trolled land will be certified, but it is constrained by the authentication of land rights in Government Law Number 24 Year 1997 on Land Registration. The method used is statute approach and conceptual approach. Analysis is conducted qualitatively by pointing out the principles and procedural law as well as analyzing social, economic and political factors in procedural and substantive process of case completion. Factors causing the local government reluctant to release regional assets is the issue to discuss in this paper to increase local revenue derived from the utilization of local land through giving Land Use Permit and Building Rights Title (HGB) above the land of management rights. The result shows that comprehensive inventory management through the registration of management right certificate of local government for the sake of protection and legal certainty is necessary.
\end{abstract}

Keywords: Management Rights, Local Finance, Local Government, Local Revenue

\begin{abstract}
Abstrak
Status tanah hak pengelolaan Pemerintah Kota Surabaya yang dikenal dengan surat ijo, menuai banyak perdebatan dengan sejumlah warga terkait dengan penguasaan dan pengelolaan atas tanah tersebut. Warga menghendaki tanah yang dikuasai akan disertipikatkan namun terkendala pembuktian hak atas tanah dalam Peraturan Pemerintah nomor 24 Tahun 1997 tentang Pendaftaran Tanah. Metode yang digu-nakan adalah metode pendekatan perundang-undangan (statute approach) dan pendekatan konsep (conceptual approach), analisis dilakukan secara kualitatif, dengan menge-tengahkan prinsip-prinsip dan prosedural hukum serta menganalisis berbagai faktor-faktor sosial, ekonomi dan politik dalam proses prosedural dan subtansif penyelesaian kasus. Faktor penyebab pemerintah daerah tidak ingin melepaskan aset daerah merupakan isu yang akan dikaji dalam tulisan ini dalam rangka meningkatkan Pendapatan Asli Daerah yang bersumber dari pemanfaatan tanah aset daerah, melalui pemberian Izin Pemakaian Tanah maupun pemberian HGB diatas tanah hak pengelolaan. Hasil akhir diperlukan inventarisasi pengelolaan secara komprehensif melalui pendaftaran atas sertipikat atas hak pengelolaan pemerintah daerah dalam rangka perlindungan dan kepastian hukum.
\end{abstract}

Kata Kunci: Hak Pengelolaan, Keuangan Daerah, Pemerintah Daerah, Pendapatan Asli Daerah

\section{Introduction}

The Preamble to the 1945 Constitution of the Republic of Indonesia contains the objectives of a state, one of which forms an Indonesian Government that protects all the people of Indonesia and the entire homeland of Indonesia

$\Omega$ This paper is part of research of Penelitian Unggulan Perguruan Tinggi, with contract number: 018/SP2H/ LT/DRPM/II/2016, Model Pengelolaan Dan Perlindungan Tanah Aset Daerah Dalam Rangka Peningkatan Pendapatan Asli Daerah Untuk Kesejahteraan Rakyat, February $17^{\text {th }}, 2016$ and to enhance public welfare. Welfare assurance shall be the Government obligation and responsibility which is essentially the people's right. The responsibility for the fulfillment of rights including welfare assurance is not limited to the Central Government but also to the Local Government. The system of regional autonomy as mandated by the constitution especially Article 18, Article 18 A and Article 18 B of the 1945 Constitution of the Republic of Indonesia grants authority to the Local Government 
to autonomously maximize its regional potentials and achieve people welfare. This must be understood not only as effort to achieve regional welfare but also national welfare. It is closely related since it reduces budget allocation to the regions which automatically the budget can be used and optimized by the Central Government to achieve broader welfare that is national welfare.

In the context of the implementation of regional autonomy, a real and responsible submission, delegation and assignment of government to the regions must be followed by the regulation, distribution and utilization of national resources fairly including the financial balance between the central government and local government. The implementation of local government and its services is based on the principles of transparency, participation, and accountability. ${ }^{1}$ In addition to the implementation of regional autonomy, people empowerment in this case can be optimized by more emphazing on efforts to improve the dignity of the layers of society which in the present condition is not able to escape from the poverty and backwardness. In other words, empowering people means enable people to be self-dependent. $^{2}$

To realize the implementation of regional autonomy and to achieve welfare, one of the indicators of efforts that can be done by Local Government is optimizing the local revenue. ${ }^{3}$ The ability of a region to explore local revenue will affect the development and growth of a region, the greater the contribution of the local revenue to the regional budget, the smaller the dependence on central government assistance. ${ }^{4}$ Economic growth also affects on the

Indrajati Hertanto and Jaka Sriyana, "Sumber Pendapatan Asli Daerah Kabupaten dan Kota", Jurnal Ekonomi dan Studi Pembangunan, Vol. 12 No. 1, April 2011, pp. 76-77

2 Fajar Sidik, "Menggali Potensi Lokal Mewujudkan Kemandirian Desa", Jurnal Kebijakan dan Administrasi Publik, Vol. 19 No. 2, November 2015, p. 119.

3 Steven Sampelan, "Analisis Kontribusi Pajak Daerah Terhadap Pembangunan Daerah Kota Manado", Jurnal Pembangunan Dan Keuangan Daerah, Vol. 10 No. 2, 2013, p. 1.

4 Cherrya Dhia Wenny, “Analisis Pengaruh Pendapatan Asli Daerah (PAD) Terhadap Kinerja Keuangan Pada increase of local revenue as the main source of local government budget to carry out its regional development. Areas with positive economic growth are likely to have an increase in local revenue. This should make local governments more concentrate on empowering local economic power to create economic growth rather than simply issuing legislation products related to taxes or user charges. ${ }^{5}$

Local Revenue can be seen as one of the indicators or criteria to measure the level of a regional dependence to the central government. The financial capacity of a region can be seen from the size of the local revenue a region yields. In principle, the greater contribution of the local revenue to the Regional Revenue and Expenditure Budget indicates the lower level of regional dependence on the central government. ${ }^{6}$ Increase of local revenue must be done by Local Government to finance their own needs to decrease its dependence to Central Government and eventually the region can be independent in Law Number 33 Year 2004 regarding the financial balance between the central government and local government, through local taxes and levies. ${ }^{7}$

Local revenue as stipulated in Article 1 point 18 of Law number 33 Year 2004 regarding Central and Regional Financial Balance is defined as regional income collected according to the Regional Regulations suitable with the laws and regulations. The income may be obtained from local taxes, regional charges, the result of separated regional wealth management, and other valid Locally-Generated Revenue. Efforts to increase the PAD can be done in various

Pemerin-tah Kabupaten dan Kota di Propinsi Sumatera Selatan", Jurnal Ilmiah STIE MDP Forum Bisnis dan Kewirausahaan, Vol. 2 No. 1, September 2012, p. 40

5 Ayu Desmawati, Zamzami, Zulgani, "Pengaruh Pertumbuhan Ekonomi Terhadap Pendapatan Asli Daerah Kabupaten/Kota di Provinsi Jambi”, Jurnal Perspektif Pembiayaan dan Pembangunan Daerah, Vol. 3 No. 1, July-September 2015, p. 50.

6 Hasan Basri, Syaparuddin, Junaidi, "Pemetaan Kinerja Pendapatan Asli Daerah dan Kemampuan Keuangan Daerah Kabupaten/Kota di Provinsi Jambi”, Jurnal Perspektif Pembiayaan dan Pembangunan Daerah, Vol. 1 No. 2, Octo-ber 2013, p. 81.

Abid Muhtarom, "Analisis PAD (Pendapatan Asli Daerah) Terhadap Kesejahteraan Masyarakat Kabupaten Lamongan Periode Tahun 2010-2015", Jurnal Ekbis, Vol. XIII No. 1 March 2015, pp. 659-660. 
ways, one of which is management and protection of local assets. Assets are an indispensable resource in governance. In relation to the implementation of regional autonomy, one of the important elements for the efficient management of local government finances is the optimum management of regional assets. This is in line with the regulation in Government Regulation Number 58 Year 2005 on Regional Financial Management, stated that one of the scopes of Regional Financial Management is the Management of Regional Property. Assets in the management of local government are not only those owned by local government but also other parties' assets controlled by the local government in order to service or execution of duties and functions of local government. The management of local assets must be properly managed to be initial capital for local governments to develop their financial capacity. Otherwise, the asset becomes a cost burden because some of the assets require maintenance or maintenance costs and value depreciated over time.

Regional autonomy focusing on regency or city is initiated by handing over the authorities from central government to local government. Transferring those authorities in case of decentralization must be followed by submission and diversion of financing. The most important source of financing is known as local revenue of which main component comes from regional tax and retribution. The higher needs that can be paid by local revenue, the higher quality of regional autonomy and the more independence of local finance will be. ${ }^{8}$

Assets management is not a simple thing. Nowadays, there are many cases related to the lack of local asset management causing loss or descent value of local assets. Moreover, this will bring large impact on the local revenue decrease which should be gained from assets management. One of problematical potential assets is land. Land in several regions is a problem to be solved to have optimum function

8 H. Mat Juri, "Analisis Kontribusi Pajak Daerah Dan Retribusi Daerah Terhadap Pendapatan Asli Daerah (PAD) Kota Samarinda", Jurnal Ekonomi dan Bisnis (Eksis), Vol. 8 No. 1, March 2012, p. 2021. and value. For example in Surabaya, land of Surabaya government remains problematical. This land with management right status has not been well inventoried which causes many problems appear. If those problems are immediately solved and optimization of asset management is conducted, local revenue will undoubtedly increase.

By looking at explanation above, this paper tries to analyze how government conducts the efforts to increase local revenue derived from the utilization of land as regional asset through providing Land Use Permit and Building Title Rights above Management Rights in case of regional asset protection.

\section{Research Method}

This research is legal research which can give suggestion about regulating and managing as well as utilizing land as regional asset in implementing regional governance. It used statute approach focusing on valid rregulations as the effort to analyze hierarchical relationship, consistency, and congruence between local asset management regulation and other regulations. This research also used conceptual approach by examining and analyzing concepts and theories on local government, regional asset related to the position of land as one of local revenue sources which should be managed well to create people's welfare. Besides, this research is also conducted by using case study approach by analyzing and examining case related to problem that is discussed. The problem is analyzed qualitatively either by presenting the principles of law (like legal principles of regulation) and its legal procedural requirement (mechanism) or analyzing many social, economic, political factors in the process of influencing procedural and substantive completion of controlling local land case.

\section{Discussion}

The data shows regional government (Surabaya, Batu, Banjarmasin city) control land with its management and use rights. Management rights is a right of a state to manage which half of its conduct is given to land hol- 
ders. The management right holder deserves to: first, plan the land use and target; second, Use the land to do his duty; third, give part of the land to third parties with certain rights.

Based on those authorities, the holder can give part of the land to third parties. The mechanism is governed in Regulations of the State Minister of Agrarian Affairs Number 9 Year 1999 on procedure in giving and canceling management rights of state land. To do so, it must initially obtain designation in form of agreement of using the land from holder of management rights and after that requested for rights as ruled in Article 4 paragraph (2) Regulations of the State Minister of Agrarian Affairs/ Head of National Land Authority Number 9 Year 1999. Meanwhile, right of use is a right to make use or take benefits from land authorized by State, or by other person who gives authority and obligation determined from agreement with landlord. Moreover, the agreement is not rent agreement or manage agreement. right of use might be either limited or not limited by time. Right of use by regional government is not limited, therefore it cannot be transferred and must be registered. Hence, if there any needed party so it can be done by rights of use relinquishment (Article 45 Government Regulation Number 40 Year 1996). After the land relinquished, it will belong to state land again and the party that need must submit request of rights.

Indonesia development requires the given management rights to be revised compatible with law principles and philosophical, juridical, and sociological aspects. Law fact shows that development in Indonesia requires management rights as a part of country authorization and must be handled immediately to solve poverty, population inequality, and geographical location of Indonesia, centralized development and effect of abandoned land. Balancing the use of management rights for low economic class with limited access is a dream a state must realize. Tendencies of land management rights in economic commodity for speculative interest and less community-oriented must be preventively or repressively handled by national regulation system. ${ }^{10}$

Regional asset or regional property according to goverment regulation Number 27 Year 2014 on State/regional-owned property management including item brought or obtained from regional budget, item obtained from another legal resources which consist of: first, item from endowment or the like; second, item from agreement or contract; third, item from law provision; fourth, item from court decision which have permanent legal force.

To optimize regional assets, especially in the form of land, local government as subject that holds management right can give building right over the management rights to the third party. They need land which are in control of local government. The mechanism of giving building rights over the management right refers to Government Regulation Number 40 Year 1996.

Land Use Permit as One of the Management Models and Land Asset Protection

Management model and land asset protection through land use permit is a new issue in National Agrarian Law system. Law Number 5 Year 1960 has not discussed this issue. Article 16 paragraph (1) Law Number 5 Year 1960 sets out kinds of land rights, such as right of ownership, cultivation rights, building rights, rights to use, lease rights, land clearing rights, rights to collect forest products, rights set by Law. Meanwhile there are rights which temporary such as: lien, profit sharing rights, rights to join, land lease rights. Land use permit based on Regional Regulation of Surabaya Number 3 Year 2016 on Land Use Permit which revokes Regional Regulation of Surabaya Number 1 Year 1997 on Land Use Permit that is a permit given by mayor or officials who are appointed to use the land and not granting rights of use or other rights above other lands as regulated in Law Number 5 Year 1960. Furthermore it is also mentioned that land use permit license is a land which is leased by Regional Government of Surabaya to certain citizens. As the evidence of people who rent the land or usually called as 
land management rights, they are given a certificate with a green paperback, people give the name to land management right as a land with "green certificate" or green letter.

It is in accordance with provision in Article 1 paragraph (3) of Regulation of Agrarian Minister/Head of National Land Agency Number 9 Year 1999 which mentions that regional government of Surabaya is one of selfrural areas that earned the delegation of land management rights from government deciding that management right is right of state to control and half of authority of its implementation is given to the holder. The purpose is to support government's activity. Referring to provision Article Number 16 paragraph (1) Law Number 5 Year 1960, Land Management Rights explicitly does not exist in Law Number 5 Year 1960. The term of management is mentioned in General Explanation Point II Number 2 Law Number 5 Year 1960, that is:

"A state can give the land to someone or legal entity with certain rights based on purpose and necessities, such as ownership rights, cultivation rights, building rights, and rights to use or give it in the management to some authority institutions to be used in their own duties."

It is known that management right is part of rights of the state to control the land where the state bestowed half of the authority to certain department, directorate, or self-rural areas. Based on Article 3 of Regulation of Home Affairs Minister Number 5 Year 1974 mentions that Management rights is to give the authority to: first, plan the allotment and the use of the land; second, make use of the land as their need to implement business; third, give parts of the land to the third party according to the set regulation by rights holder that covers allotment, utilization, time period and finance, with the regulation that the given rights to the third party is done by the authorized officials based on Ministry of Home Affairs Regulation Number 6 Year 1972 on "Handing Over Authority of Giving Land Rights", in accordance with applicable laws and regulation.
Further provisions about Land Use Permit in Surabaya, which aligned the position with HPL, based on Article 3 Government Regulation Number 3 Year 2016 mentioned as follows:

(1) Use of land is permitted to the need party or as individual or institution, as long as it is not used by the Regional Government itself.

(2) Used of land involves the use in form of on, in, above, crossed or penetrate the land.

Land Use Permit is distinguished as follows:

a. Long-term IPT, applicable until 20 (twenty) years and can be extended at most every 20 (twenty) years particularly for business or residence;

b. Medium-term IPT, applicable until 5 (five) years and can be extended at most every 5 (five) years;

c. Short-term IPT, applicable until 2 (two) years and can be extended at most every 2 (two) years.

If the land use permit is due, the land control will return to Regional Government (in case Regional Government of Surabaya). Therefore, before it is over, if the holder wants to occupy the land, they must extend the permit. Here is the process to extend the permit stipulated by Regional Government of Surabaya in Figure 1.

People get the permit without land certificate but they can ask for building rights over the management rights to the permitted land. Application process of building rights is regulated in Mayor Decree of Regional Head Level II Surabaya Number 27 Year 1995 on Procedure of gaining Building Rights upon Management Rights of Regional Government Level II Surabaya. This will be the basic analysis to answer the legal issue with regard to procedure of giving Building Rights upon Management Rights.

\section{The Grant of Right to Build upon Management Right}

The stipulation of Right to Build given upon the state and right of management lands is further regulated in Article 22 section (2) government regulation No. 40 year 1996 which regulates that Right to Build upon the land of 
Figure 1: Service Flow of Land Use Permit Extension

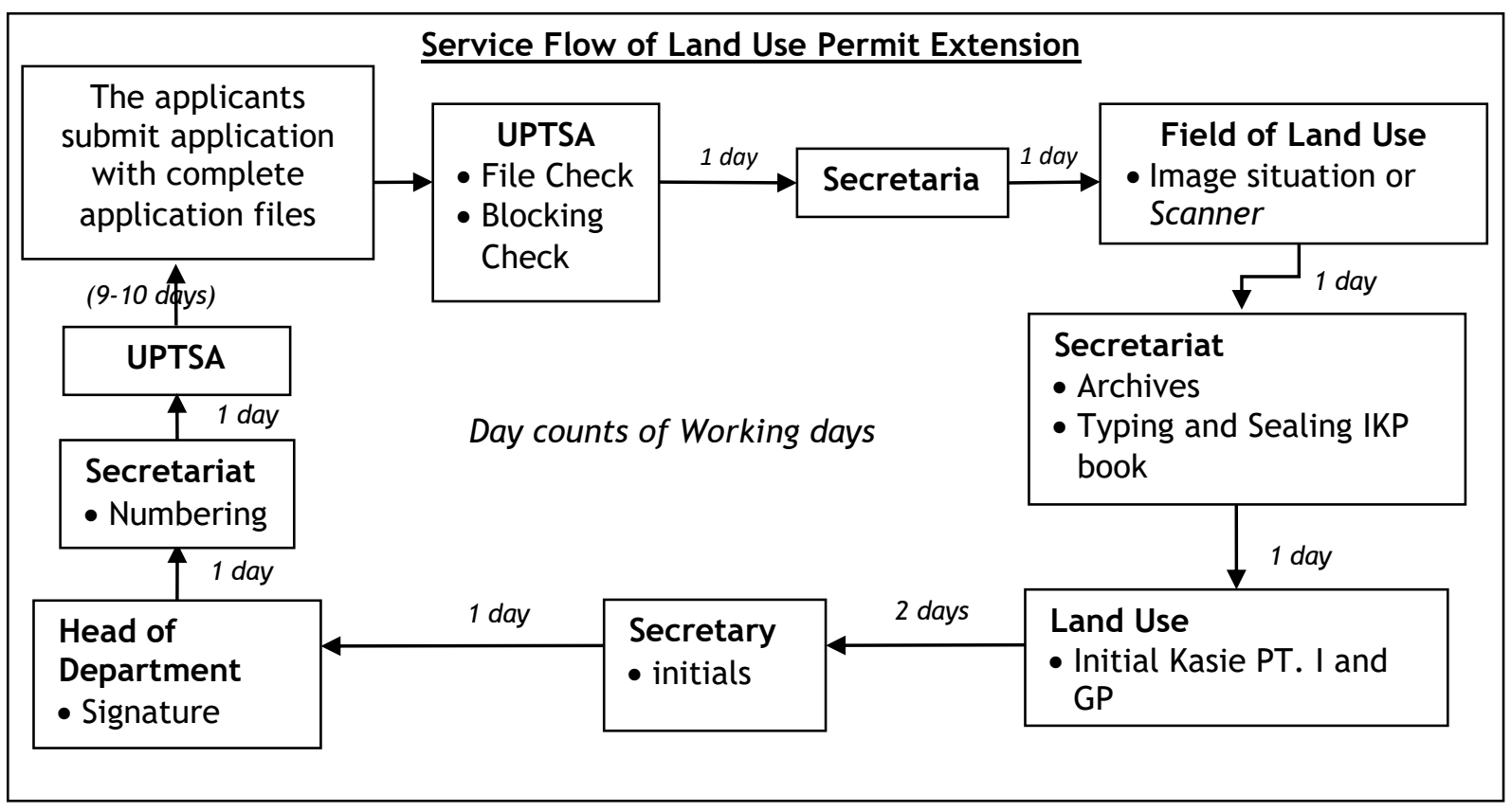

Source: Private Document

Figure 2: procedure of the Right to Build to allocation

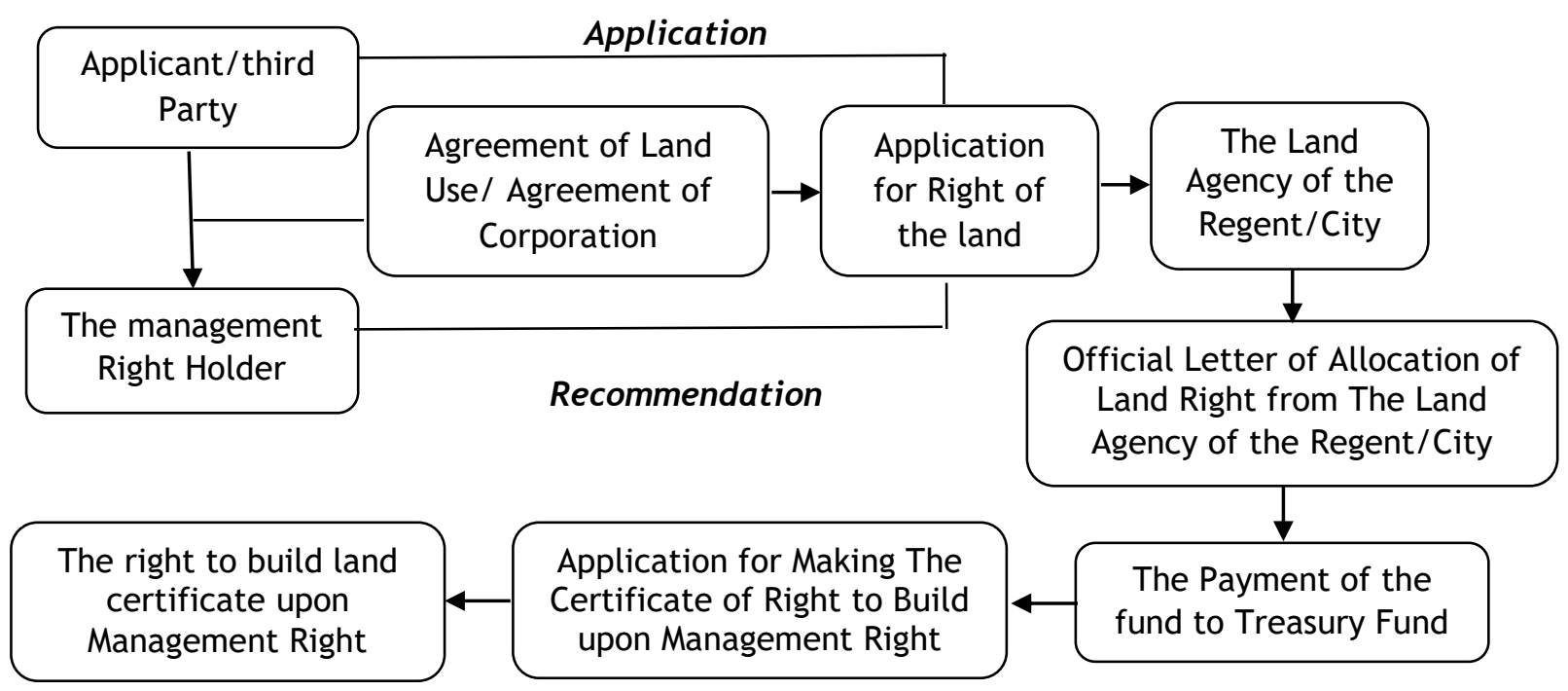

Source: Private Document 
Right of Management is given by the minister or the officer in charge based on the suggestion of Management right of land's holder. The purpose of the article is that basically the Right to Build given upon a state land or land of management right is allocated based on the decision of the Minister of Agriculture/the Head of National Land Agency by considering the Regulation of Agriculture Minister/Head of National Land Agency No. 3 Year 1999 on the Overflow of Allocation Authority and Annulment of Right of State Land Allocation Decision, especially Article 4. In the article, there is a statement mentioning that the allocation of te Right to Build upon the land of Management Right is gi-ven by the Head of City/Regency Land Agency.

Then, based on the Regulation of Agriculture Minister/Head of National Land Agency No. 9 Year 1999, the requested land is the land of management right, consequently, there should be an appointment from the land management right's holder. Based on Article 67 on the Regulation of Agriculture Minister/Head of National Land Agency Number 9 Year 1999, one of the subjects of Land Management Right is Government Agency including Regional Government. It states that Regional Government is the holder of management right, especially related to government asset lands. They are: ${ }^{9}$ first, the lands which do not belong to other parties but the government; second, the lands are managed and preserved using the government fund; third, the lands are registered in the list of government inventory; fourth, the lands are physically used by other party based on the legal relationship between that party with the government; fifth, the lands can be certificated or have not been certificated.

In line with the delivery of management right land of the government to the third party, there are some requirements in form of agreement by those parties. Based on the agreement, the third party is able to apply to get the right over the land of the management right to Local Land Agency. In the agreement, there should be

9 Maria S.W.Sumardjono, 2005, The Policy of Land Between Regulation and Implementation, Jakarta: Kompas Publisher, p. 251. certain rights given by the right of management's holder, whether it is Right to Build or Right to use. Meanwhile, the procedure of the Right to Build allocation can be seen in Article 35-39 Regulation of Agriculture Minister/Head of National Land Agency No.9 Year 1999. Simply stated, the procedure can be desribed in the Figure 1.

The procedure, especially for the Management Right belonging to the Regional Government refers to Government Regulation Number 27 Year 2014, Regulation of Agriculture Minister/Head of National Land Agency No.9 Year 1999 and Regulation of Home Affairs Ministry Number 1 Year 1977 which are shorlty explained in Figure 2.

The third party attains an appointment which is an agreement of the land use upon management right from the regional government as the management right holder based on certain agreement (corporational agreement) which grants the third party the right to build upon the right of management. Based on the agreement, the third party is responsible for paying the certain restribution set out in each Regional Regulation. Then, the application of the right to build upon the management right is filed to the Land Agency of The regency/ city by attaching certain requirements such as an agreement letter with Regional Government, Recomendation/Agreement letter from the regional government as the management right holder, payment token of the restribution, the third party identity, and Announcement Letter of Tax Debt of land and Building Tax. In addition, based on the authority of the allocation of the right to build upon the management right, the head of Regency/city Land Agency publishes Decision Letter of the allocation of Right to Build upon the management right in the name of the third party. Then, the third party registers the right to build upon the management right after he/she fulfils the responsibilities stated in Decision Letter of the right, such as paying levy to the treasury fund and Right Attainment Tax of the land and building. The Regency/City Land Agency publishes the certificate of Right to Build with certain expired date and 
large using the third party's name and it is published upon some management rights.

Related to Tax on Acquisition Rights to Land and Buildings, Ni Putu Diah Ratih Nareswari Putri added that: ${ }^{10}$

"Tax on Acquisition Rights to Land and Buildings is property tax of the land and building acquisition based on Law No. 21 Year 1997 on Land and Building Right Attainment Tax which changed into Law No. 20 year 2000. Why should the Tax Acquisition Rights to Land and Buildings be replaced to regional tax? The answer of this question may be found in Law Number 28 Year 2009 on Regional Tax and Retribution. Prior to the Law No. 28 Year 2009 , the tax is the central tax which means that central government is the one who is responsible for collecting it. Yet, after the Law is regulated, it is the tax policy which becomes the responsibility of the regency/city government and it will directly influence the local income."

The advantages of granting the management right to the Regional Government including: first, to ensure legal certainty on land rights; secondly, to secure the assets of Regional Government from other parties claims. This can be conducted by means of administrative safeguards (providing certificates and proof of land ownership), physical safeguards (fencing and installation of land titles) and legal action/ remedies in case of violation of rights or criminal acts; Third, to benefit from third parties to increase local revenue in the field of land. Obligations emerged from the agreement can increase local revenue in terms of area retribution as a form of payment for the object of retribution owned or managed locally for Regional Government for related parties' interests. Meanwhile, the payment is received at the time of signing of the agreement. Another form of

10 Ni Putu Diah Ratih Nareswari Putri, Noor Rahardjo and Henny Juliani. "The Implication of Policy of the Land and Building Right Attainment Tax as Regional Tax toward The Real Regional Income of Regency Badung, Province Bali”, Diponegoro Law Review, Vol. 1 No. 4, 2012, in Tiara Juniar Soewardi and Candra Fajri Ananda, "The Transformation of Bea Acquisition Rights to Land and Buildings (BP HTB): Case Study in Kediri City of East Java”, Procedia Social and Behavioral Science, Vol. 211, 2015, p. 1180 income is the distribution of revenue from Acquisition of Land Rights and Buildings of land rights upon the land of Management Rights which entered into the Regional Government's treasury.

Efforts to Increase Local Revenue from the Utilization of Local Assets by Granting Land Use Permit and Right to Build upon Land Management Right

Fundamental changes to the structure of Regional Government under Law of Regional Government and Law of Fiscal Balance have implications on the regulation of local financial management. Basically local financial management is an integrated part of administrative management on state finances. In relation to governance, finance is a vital aspect. Activities that will be implemented by the government will not possibly run without funds support. In other words, finance is the vital for every budget plan. This financial planning is very strategic in achieving successful implementation of development programs. Financial management seeks to optimize the source and use of funds.

Referring to regulation of Article 285 (1) of Law Number 23 Year 2014 stated that the source of regional revenue consists of: Local revenue (including: local taxes, regional retributions, result of separated area wealth management and other legitimate local revenue), transfer income and other legal regional revenue. In the context of regional autonomy, local governments are encouraged to increase local revenues for finance government expenditures in running administration. The local Revenues in this context are derived from the management of resources in the areas in accordance with the laws and regulations.

Local governments may use fees on services provided by the government and grant certain permits to cover part or all costs incurred by the government for such services or licenses. Retribution paid by levy payers is fee for the use of facilities/services provided by the government. Thus, the payers get services directly from the government. In relation to the utilization of regional assets through the me- 
chanism of granting of Land Use Permit and/or Provision of Land Use Rights on Land Rights by Regional Government as the main issue in this paper, it is important to make retribution as an instrument in the framework of local revenue improvement.

In practice, it was found that the retribution imposition by Local Government upon the granting of Land Use Permit to third parties was not that simple. For instance, it reveals that some expired Land Use Permits are still recorded in local government as potential revenue of the region. However, the previous holders feel that it is no longer their own so they are unwilling to pay retribution to the local government; in fact, they still occupy the land by the status of Land Use Permit. Based on this matter, in our opinion, the root of the problem lies on the weakness of law enforcement from the Regional Government of Surabaya. In the concept of Administrative Law, there are 2 law enforcement models, namely, preventive law enforcement (supervision and guidance) and repressive law enforcement (sanctions imposition). With high commitment of the local government, both preventive and repressive can be effectively implemented to avoid potential loss of regional revenue.

\section{Conclusion}

In order to improve regional revenue from utilization of land of regional assets, the Regional Government may collect user charges based on prevailing laws and regulations from granting of Land Use Permits and the provision of Right to Use on land of Management right to third parties. In addition, other income may also be obtained from the distribution of revenue from Tax on Acquisition of Land and Building Rights on the Right to Build upon Management Right proposed by a third party to the Regional Government. Granting Land Use Permit in the City of Surabaya refers to regulations of related legislation, such as Law Number 5 Year 1960, Regulation of the Minister of Agrarian Affairs/ Head of National Land Agency Number 9 Year 1999, Local Regulation of Surabaya Number 3 Year 2016. Procedure of Right to Use Land ma- nagement, especially Land Management Rights owned by the Regional Government refers to Government Regulation Number 27 Year 2014, Regulation of Minister of Agrarian Affairs/Head of National Land Affairs Agency Number 9 Year 1999, and the Ministry of Home Affairs Regulation Number 1 Year 1977.

\section{Suggestion}

In order to provide legal certainty for Land Usage Permit holders granted by the Local Government upon Management Rights Land, a comprehensive inventory management pattern is required based on the relevant laws and regulations. This can be done if there is prior certainty regarding the registration of land certificate for Right of Management in accordance with Government Regulation Number 24 Year 1997. In addition, it is necessary to have Local Government commitment in implementing law enforcement, either preventive or repressive, in relation to retribution on granting of Permit Land Use to third parties; therefore, no potential loss of regional revenue is expected. It is necessary to evaluate Government Regulation Number 27 of 2014 which has not explicitly accommodated in Law Number 5 Year 1960 in its consideration as a legal support related to management of regional property. Regional Government is regional assets that can increase the source of income for the region by optimizing its usage.

\section{References}

Basri, Hasan. Syaparuddin. Junaidi. "Pemetaan Kinerja Pendapatan Asli Daerah dan Kemampuan Keuangan Daerah Kabupaten/ Kota di Provinsi Jambi". Jurnal Perspektif Pembiayaan dan Pembangunan Daerah. Vol. 1 No. 2. October 2013, pp. 81-90;

Desmawati, Ayu. Zamzami. Zulgani. "Pengaruh Pertumbuhan Ekonomi Terhadap Pendapatan Asli Daerah Kabupaten/Kota di Provinsi Jambi". Jurnal Perspektif Pembiayaan dan Pembangunan Daerah. Vol. 3 No. 1. July-September 2015, pp. 49-58

Hertanto, Indrajati and Jaka Sriyana. "Sumber Pendapatan Asli Daerah Kabupaten dan 
Kota". Jurnal Ekonomi dan Studi Pembangunan. Vol. 12 No. 1. April 2011, pp. 7689, DOI: 10.18196/jesp.12.1.1273;

Juri, H. Mat. "Analisis Kontribusi Pajak Daerah Dan Retribusi Daerah Terhadap Pendapatan Asli Daerah (PAD) Kota Samarinda". Jurnal Ekonomi dan Bisnis (Ekbis). Vol. 8 No. 1. March 2012, pp. 2020-2031;

Muhtarom, Abid. "Analisis PAD (Pendapatan Asli Daerah) Terhadap Kesejahteraan Masyarakat Kabupaten Lamongan Periode Tahun 2010-2015". Jurnal Ekonomi dan Bisnis (Ekbis). Vol. XIII No. 1 March 2015, pp. 659-667;

Soewardi, Tiara Juniar and Candra Fajri Ananda. "The Transformation of Bea Acquisition Rights to Land and Buildings (BPHTB): Case Study in Kediri City of East Java". Procedia Social and Behavioral Sience. Vol. 211 Year 2015, pp. 11791185. DOI: 10.1016/j.sbspro. 2015.11. 157 ;

Rahmi, Elita. "Eksistensi Hak Pengelolaan Atas Tanah (HPL) Dan Realitas Pembangungan Indonesia". Jurnal Dinamika Hukum. Vol. 10. No. 3 September 2010, pp. 349-359. DOI: 10.20884/1.jdh.2010.10.3.104;

Sampelan, Steven. “Analisis Kontribusi Pajak Daerah Terhadap Pembangunan Daerah Kota Manado". Jurnal Pembangunan Dan Keu-angan Daerah. Vol. 10 No. 2 Year 2013, pp.1-12;

Sidik, Fajar. "Menggali Potensi Lokal Mewujudkan Kemandirian Desa". Jurnal Kebijakan dan Administrasi Publik. Vol. 19 No. 2 November 2015, pp. 115-131. DOI: 10. 22146/jkap. 7962;

Sumardjono, Maria S.W. 2005. Kebijakan Pertanahan Antara Regulasi dan Implementasi. Jakarta: Penerbit Buku Kompas;

Wenny, Cherrya Dhia. "Analisis Pengaruh Pendapatan Asli Daerah (PAD) Terhadap Kinerja Keuangan Pada Pemerintah Kabupaten dan Kota di Propinsi Sumatera Selatan". Jurnal Ilmiah STIE MDP Forum Bisnis dan Kewirausahaan. Vol. 2 No. 1. September 2012, pp. 39-51. 